\title{
From Prussia to China: Japanese Colonial Medicine and Gotō Shinpei's Combination of Medical Police and Local Self-Administration
}

\author{
CHRISTOS LYNTERIS*
}

Keywords: Gotō Shinpei; Medical Police; Manchuria; Taiwan; Biopolitics

Recent historical investigation into the rise of 'biopolitical modernity' in China has shed some surprising light. While it was long thought that British public health initiatives entered China via Hong Kong, the recent work of Ruth Rogaski ${ }^{1}$, Philippe Chemouilli ${ }^{2}$ and others has established that it was actually early Japanese colonialism that played the crucial role. It was the Meiji Empire's hygiene reform projects in Taiwan and Manchuria that provided the model for Republican China. Curiously overlooked by medical historians has been one of the major early works of Japanese public health that directly inspired and guided this colonial medical enterprise. This was that of the Japanese health reformer and colonial officer, Gotō Shinpei (1857-1929), and it was undertaken in Munich as a doctoral thesis under the supervision of Max von Pettenkofer. In this article, I focus on the way in which Shinpei dealt in his thesis with the relations between centralisation and local self-administration as one of the key issues facing hygienic modernisation and colonial biopolitical control.

Shinpei was the archetypal figure of Japanese colonialism. Born in 1857, his career as a Japanese statesman ran parallel to the development of the Meiji Period (1868-1912) that transformed a fragmented and parochial Japan into an industrialised modern world power. From the early 1880s, in particular, Japan experienced major governmental and scientific innovations, which were ushered in through European luminaries and soon spread to the new colonies in China. Before his death in 1929, Gotō officiated in posts as diverse as Chief Civilian Administrator of Taiwan, Director General of the South Manchurian Railway, Mayor of Tokyo, and Home Minister of Japan. By the age of twenty-five, his academic excellence and allegiance to the Emperor was such that he was appointed the Chancellor of Nagoya Medical School.

Medical historians have recently provided some important insights into the contributions of Gotō Shinpei to the introduction of Japanese colonial medicine and public health in China. Shiyung Liu (2008) has demonstrated how Gotō's placement as Minsei Chôkan [Chief Civil Administrator] of Taiwan in 1898 opened the way for pupils of Japan's leading medical scientist, Kitasato, to remove themselves from direct state

(C) Christos Lynteris 2011.

\footnotetext{
${ }^{1}$ Ruth Rogaski, Hygienic Modernity, Meaning of Health and Disease in Treaty-Port China (Berkeley, CA: University of California Press, 2004).
}

${ }^{2}$ Philippe Chemouilli, 'Le Choléra et la Naissance de
la Santé Publique Dans le Japon de Meiji';
Médecine/Sciences, 20 (2004) 236-40. 


\section{Christos Lynteris}

control and apply their novel ideas on the new colony. ${ }^{3}$ Similarly, Cheng-yi Huang (2008) has shown how Gotō's mobilisation of German-trained jurists and sociologists, such as Okamatsu, led to the groundbreaking survey of Taiwan's population, and to an extensive study of local customs, property concepts and practices, as well as to the social organisation of local communities across Taiwan. ${ }^{4}$ Most importantly, Chin Hsien-Yu (1998) has shown how medical expertise and ethnographic observation under the command of Gotō Shinpei led to the revitalisation of the baojia system of community mutual policing in Taiwan through its integration with a system of residence known as the hokou. ${ }^{5}$ By this system, elected leaders of households were placed in charge of community surveillance and hygienic discipline, an organisation that was to form the spine of the colonial medical police system. Apart from informing on 'dangerous thoughts' and resistance activities, this apparatus was 'in charge of eradicating noxious insects, combating epidemics, and preventing the spread of contagious diseases from one area to another'. ${ }^{6}$ The efficacy of this system of combining centralised medical police control with a vast molecular system of co-opted local self-administration became evident not just in the increased numbers of arrested insurgents, but also in the successful containment of epidemics.

Gotō implemented the same system of controlling local populations when he was appointed Director of the South Manchurian Railway in 1906. Manchuria was more complex than Taiwan, however, since it was not a Japanese dominion but a territory covered by intricate multilateral treaties that guaranteed economic control but inhibited territorial expansion to mainland China. Gotō was eager to proclaim the values of 'scientific colonialism', envisioning a mass transformation of Manchuria by the forces of science, technology and engineering. As in Taiwan, this strategy was based on a careful study of local customs, concepts and practices of justice, kinship and land-ownership. This combination of central medical police command with co-opted local self-administration placed Japan in a unique position at the break of the Manchurian Pneumonic Plague of $1910-11 .^{7}$

Whereas all this is common currency in the historiography of Japanese colonial medicine, the focus usually falls on Japan's corporatist and even racist attitudes towards the colonised population. Thus, the relationship of the medical police system to modes of local self-administration is usually seen as tactical, whereas in fact it was programmatic and strategic. As a consequence, what I want to argue here is that what really connected Gotō's biopolitical projects in Taiwan and Manchuria was his innovative combination of medical police and local self-administration, the blueprint of which is found in his doctoral thesis, 'Vergleichende Darstellung der Medizinalpolizei und Medizinalverwaltung

\footnotetext{
${ }^{3}$ Shiyung Liu, 'The Ripples of Rivalry: The Spread of Modern Medicine from Japan to its Colonies', East Asian Science, Technology and Society: An International Journal, 2 (2008) 47-71.

${ }^{4}$ Cheng-yi Huang, "Enacting the "Incomprehensible China": Modern European Jurisprudence and the Japanese Reconstruction of Qing Political Law', Law \& Social Inquiry, 33, 4 (2008), 955-1001.
}

\footnotetext{
${ }^{5}$ Chin Hsien-Yu, 'Colonial Medical Police and Postcolonial Medical Surveillance Systems in Taiwan, 1895-1950s', Osiris, 2nd Series, 13 (1998), 326-38.

${ }^{6}$ Ibid., 329.

${ }^{7}$ Carl F. Nathan, Plague Prevention and Politics in Manchuria 1910-1931 (Cambridge, MA: Harvard East Asian Monographs, 1967).
} 


\section{From Prussia to China}

in Japan und anderen Staaten' ['A Comparative Study of Medical Police and Medical Administration in Japan and Other States']. ${ }^{8}$

Completed in 1891, the thesis is composed of a short introduction and two main parts. The first part, entitled 'Organisation', is a description of the organisation of the health system in Japan at the time. The first subsection entitled 'Zentralorgan' ['Central Organ'] describes the purpose, structure and function of the Japanese Sanitary Bureau and of the Central Sanitary Bureau. After describing in detail the duties of each apparatus, Gotō proceeds to give an account of similar structures in various European countries, focusing at length on the opinions of Lorenz von Stein on the function of the German health system in terms of public justice. The second subsection, entitled 'Landesorgane' ['Local Organs'], begins with a description of Japan's local health apparatus and its division into fundamental sectors of 'Selbstverwaltung' ['self-administration']. It then proceeds to compare health systems in Europe and North America. Gotō next turns his attention to local health co-operatives, which he describes as 'a form of self-administration and of great importance for public health care'. 'After a description of the Japanese Hygienic Association, he concludes by reference to statistical survey systems in Japan and Europe. The second part of the thesis has the general title 'Leistungen der öffentlichen Gesundheitspflege' ['Achievements of Public Health Care'] and is divided into ten subsections, each describing different aspects of public health (burial grounds, abattoirs, etc.). The thesis concludes with a discussion of the comparative merits of different public health systems in Europe and the USA, with special reference to their relevance and applicability to Japanese reality. With this synopsis in mind, let me turn now to the main points of the thesis, focusing on Gotō's innovative perspective regarding the relationship of central colonial command and local self-administration.

Gotō's thesis is a staunch defence of the Prussian model of medical police. It begins, characteristically:

Medicine, both theoretically and practically, is on the front line of the sciences which in the second half of the century saw an incredible development. Until the midst of the last century it had (in Europe) only the character of managing disease and the discoveries of physiologists and pathologists were applied only in a small circle of people. Then the time came when medicine acquired political rights, and by supporting and defending the state, it too found support in the ever-expanding medical legislation. In this way a gradual change occurred in the perception of the position of medicine, where 'hygiene', that is the public care for health, an initially small, little cultivated, secondary branch of this science, was raised despite many obstacles, to a dominant position, so that today the object of medicine in both theory and practice is in effect no longer man as a human being but as a citizen. ${ }^{10}$

Striking is Gotō's insistence on the vitality of co-ordinating administration and public justice. Their connection, as vital to the development of a comprehensive and effective public health system, is the main concern of the first part of the thesis where he quotes Lorenz von Stein at length regarding the problems facing Prussia, due to the separation

\footnotetext{
${ }^{8}$ Gotō Shinpei [Gotoh Shimpei], 'Vergleichende Darstellung der Medizinalpolizei und Medizinalverwaltung in Japan und anderen Staaten'
}

(unpublished MD thesis: Ludwig-Maximilians-

Universität München, 1891).

${ }^{9}$ Ibid., 13.

${ }^{10}$ Ibid., 1. 


\section{Christos Lynteris}

of juridical and administrative powers. Gotō's conclusion is sharp: 'The best form for administrating health is a central executive power with scientific counselling support, as applied in the case of the organisation of the Japanese central administration. ${ }^{, 11}$

Given the emphasis on centralised organisation, it might be supposed that Gotō's ideas on medical police simply reflect notions of centralist government. This would be wrong, however; for Gotō, it was Prussia which provided the ideal model for his Japanese vision of biopolitical modernity, and in Prussia it was not centralisation that carried the day, but rather, its combining of central medical police control with local self-administration. In contrast, France's system of public health was described as deplorable, precisely due to the 'the old bureaucratic form of health administration, in which there is not a trace of self-administration'. ${ }^{12}$ Thus, it is not surprising that as much as double the space is given to the discussion of local organs of health administration, making clear that while Gotō shared von Stein's opinions on the necessity of a central legislation, he also conceived the application of this as optimally localised and self-administrated. The praise of the enclosure of local modes of self-administration as part of biopolitical modernisation is explicit in the thesis:

In most centres of self-administration, towns and villages, health issues are administered by the president of the community. Besides that, most communities have created so-called hygienic cooperatives [Yeisei kumiai] where citizens of a neighbourhood cooperate based on a voluntary contract with a superior for the performance of specific measures of public hygiene. These cooperatives, which have no parallel in Europe, are in Japan of the highest importance for the care of the health of the people, especially in communities and villages. ${ }^{13}$

Gotō concludes his thesis by arguing that the merit and uniqueness of the Japanese public health model, and hence the element needing reinforcement, is the co-ordination of a centralised administration and a broadened self-administration.

The composition of Gotō's thesis and his invention of a colonial biopolitical system that combined centralised medical police and local self-administration was situated within a climate of tension in Japan over the role of hygienic associations and co-operatives. Whereas originally these local self-administrating units had been favoured by the Meiji hygienic reformers, in 1886 they were subordinated to a non-reflexive and static system of central police command. This development has been described by some medical historians as a veritable coup d'arrêt, informed by the increasing Prussian influence on Japanese statecraft leading to the first Meiji Constitution. ${ }^{14}$ Gotō, both a defender of Prussian corporatism and an original sponsor of the hygienic co-operatives system, thus found himself in a governmental double bind, which he sought to resolve first theoretically, in his thesis, and then practically, as a colonial master.

Through his public health reform programme in Taiwan and Manchuria, Gotō's medical colonialism did not aim to repress local self-administration, but rather to invest it with a new mode of organisation, the medical police system. Basing his policy on the heterodox, if no less racist, premise that civilisation cannot be plugged into the colo-

\footnotetext{
${ }^{11}$ Ibid., 8.

${ }^{12}$ Ibid., 30.

${ }^{13}$ Ibid., 9.
}

\footnotetext{
${ }^{14}$ For example, Philippe Chemouilli, op. cit. (note 2).
} 


\section{From Prussia to China}

nies $^{15}$, Gotō envisioned a rationalisation and standardisation of local systems of selfadministration under the gaze of a centralised colonial command. If the natives cannot be civilised by virue or by force, Goto reasoned, the only possible way to rule them is through their own means of self-administration. It was a means that proved particularly effective during epidemics as during uprisings, and it all predated British 'indirect rule' by several decades.

\section{Acknowledgements}

The research on Gotō Shinpei's thesis was funded by the Thomas and Margaret Roddan Trust, and was conducted as part of my doctoral research funded by a scholarship of the Department of Social Anthropology of the University of St Andrews. Many thanks are owed to Emily Stavridis for the translation of the thesis from German and to Professor Akihito Suzuki for his feedback on the paper during 'The Future of Medical History' conference at The Wellcome Trust Centre for the History of Medicine at UCL.

\footnotetext{
${ }^{15}$ This belief was exemplified in Gotō's infamous but little understood diatribe on the futility of trying to transplant the eye structure of a flatfish into a sea bream.
} 